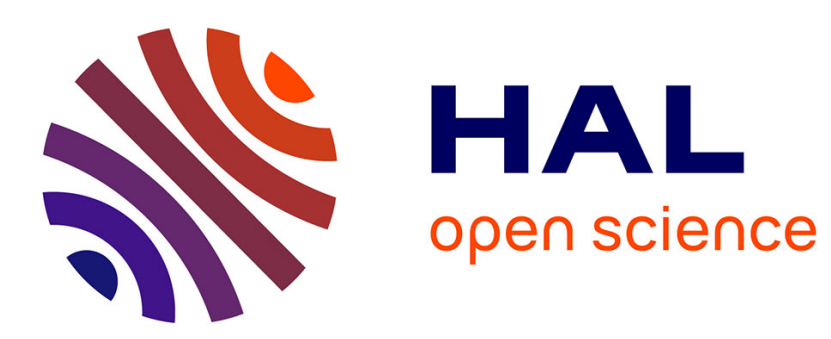

\title{
The vital city: public analysis, dairies and slaughterhouses in nineteenth-century Britain \\ Chris Otter
}

\section{To cite this version:}

Chris Otter. The vital city: public analysis, dairies and slaughterhouses in nineteenth-century Britain. cultural geographies, 2006, 13 (4), pp.517-537. 10.1191/1474474006cgj373oa . hal-00572175

\section{HAL Id: hal-00572175 \\ https://hal.science/hal-00572175}

Submitted on 1 Mar 2011

HAL is a multi-disciplinary open access archive for the deposit and dissemination of scientific research documents, whether they are published or not. The documents may come from teaching and research institutions in France or abroad, or from public or private research centers.
L'archive ouverte pluridisciplinaire HAL, est destinée au dépôt et à la diffusion de documents scientifiques de niveau recherche, publiés ou non, émanant des établissements d'enseignement et de recherche français ou étrangers, des laboratoires publics ou privés. 


\title{
The vital city: public analysis, dairies and slaughterhouses in nineteenth-century Britain
}

\author{
Chris Otter
}

Department of History, New York University

\begin{abstract}
Despite the premises of classical political economy, which urged limited intervention in the production and circulation of vital commodities, nineteenth-century British government became heavily involved in the urban food supply. This paper explores three areas where such governmental intervention was evident: the constitution of a network of public analysts devoted to the chemical sampling of foodstuffs, the increasing regulation of the dairy industry, and the construction of public abattoirs. Although these regulatory systems suggest an active, interventionary form of government, they can still be seen as broadly liberal in nature: they usually involved a substantial degree of delegation, pragmatism and negotiation, and their implementation was slow and geographically patchy. Nonetheless, substantial changes in urban nutritional practices can be discerned by 1900. By this time, little food was produced within British cities: much came from remote parts of Britain or overseas, and the supply was far more technologically-mediated than in earlier centuries. In the milk and meat trades, we can see the first moves towards industrialisation. Securing the vitality of the city, therefore, had entailed the development of distinct regulatory strategies and the emergence of new nutritional geographies, both of which would significantly shape the dietary history of the twentieth century.
\end{abstract}

During the nineteenth century, feeding Britain's pullulating urban population became a specifically social problem. Rather than being left to the autonomous mechanisms of a free market, the vagaries of nature or the whims of God, supplying food of adequate quality and quantity gradually fell within the ambit of government. This paper studies three specific sites where feeding the city became recognizably problematic: adulteration, and the supply of milk and meat. Public analysts were appointed to monitor the physical constitution of foodstuffs, for example, while the legal form of slaughterhouses was regulated. The historical emergence of these distinct regulatory strategies tells us much about British political culture, while the ensuing spatial arrangements produced novel nutritional geographies. Milk and meat, for example, were commonly produced within cities for most of the century, but by 1900 , dairying and slaughter were vanishing from urban life. The networks securing the city's food were becoming longer, more technologically mediated, and concentrated: they were also exposed to an increasing amount of inspection. Before investigating these 
vast geographical processes, however, I will make some general introductory remarks about the politics of food supply in nineteenth-century Britain.

Regulation of the food supply, in any form, was in no way an inevitable development. The very lack of strong state involvement in food was often upheld as demonstrable proof of the efficacy of economic liberalism. 'Of all things,' intoned Edmund Burke in 1795, 'an indiscrete tampering with the trade of provisions is the most dangerous'. ${ }^{1}$ Burke compared the English approach with the French, where the state's control of food prices meant that it was blamed for high prices or dearth. By mid-Victorian times, such sentiments were commonplace. 'It is useless to ask by what central authority, or under what controlling system, is such a city as London supplied with its daily food,' boasted the journalist George Dodd in The food of London (1856). ${ }^{2}$ In 1891, Herbert Spencer observed how cities were fed by the combined action of many invisible hands, rather than state regulation. Liberal societies, he noted:

spontaneously evolve that wonderful system whereby a great city has its food daily brought round to all doors or stored at adjacent shops... production as well as distribution is similarly carried on which the smallest amount of superintendence which proves efficient. ${ }^{3}$

Yet the rather ingenuous premise that the market alone could nourish the city was attacked from numerous directions across the century. Well before the Irish famine, for example, certain doctors and social observers argued that hunger and even starvation were common among the urban poor. ${ }^{4}$ William Farr listed 63 deaths from starvation in his first report for the Registrar-General in 1839. ${ }^{5}$ More commonly, hunger predisposed the body to infection or debilitation. Writing in Manchester in 1839, Richard Howard observed that:

in persons labouring under an impaired state of health from deficiency of food, there is a remarkable susceptibility to the effects of contagion, unwholesome conditions of the atmosphere, vicissitudes of the weather, and, in short, to all the existing causes of disease. ${ }^{6}$

In particular, young and old bodies failed to generate sufficient heat when hungry and emaciated: deaths spiked in winter as a consequence. Howard suggested that this damaged the 'moral and intellectual' aspects of a person as well as the physical, thus 'vitally affecting the well-being and prosperity of a nation'. ' In National distress (1844), Samuel Laing estimated that around a third of Britain's workers were 'hovering on the verge of absolute starvation'. 8 The quality of urban food also attracted concern. The urban poor, according to Howard, live much on innutritious and indigestable food, and often use articles of bad quality, or such as are rendered unwholesome by adulteration, or by being kept too long'. Stale, rotting or adulterated food, he concluded, often stimulated the desire for the evanescent, numbing powers of drink. James Kay, meanwhile, found the Mancunian bread and potato diet monotonous and insubstantial. ${ }^{10}$

Kay's solution to such dietary ills was, generally, a liberal one: abolition of the Corn Laws and other impediments to freedom of trade. ${ }^{11}$ Others, however, were arguing that something more paternalistic or even socialistic was required. Some doctors suggested that if poor diet acted as a cause of illness (predisposing or otherwise), then the poor 
should be given food rather than medicine. ${ }^{12}$ Howard concluded that the soup kitchens established in 1837 'demonstrated, very clearly, the advantages of supplying food, rather than money, to the poor, on such occasions'. ${ }^{13}$ The persistence of outdoor relief and almsgiving during economic downturns demonstrated the limits of strict political economy: laissez-faire, as Karl Polanyi showed long ago, was never a feasible practice in such circumstances. ${ }^{14}$

Parallel and not unconnected to such debates were the first scientific attempts to accurately quantify human dietary requirements, in terms of the new triad of carbohydrate, fat and protein. ${ }^{15}$ In 1849-50, the chemist Lyon Playfair analysed workhouse dietaries and developed diets appropriate for specific activities from convalescence, or pure subsistence, to hard labour. ${ }^{16}$ More extensive research in the early 1860s by Edward Smith, Medical Officer of the Poor Law Board, established standard diets for workhouse inmates. ${ }^{17}$ Playfair concluded that a man undertaking hard labour had a daily dietary requirement of 6.5 ounces of nitrogenous food (protein), 2.5 ounces of fat and 20.0 ounces of starch. ${ }^{18}$ By the 1860s, such figures, however crude or contested, were becoming common in public health and hygiene manuals: a certain daily quantity of nutriment, in principle, was the right of all.

Certain kinds of institution operated as dietetic laboratories. Soldiers, for example, were regarded as 'highly suitable for experiments of th[is] kind, their regularity in diet and occupation, and their habits of obedience, affording a special guarantee for the precision with which they can carry out the instructions given'. ${ }^{19}$ Prisons, hospitals and workhouses allowed administration of controlled quantities of food, and easy observation of the consequences. Following scrutiny of workhouse dietaries in the 1860s, Smith recommended 'a fundamental guiding principle - one of rigid utilitarianism - viz., that the inmates of workhouses should be fed in a manner the most consistent with economy and the maintenance of growth, health, and strength'. ${ }^{20}$ Strict Benthamite principles of deterrence were, however, giving way to a less punitive concern for collective vitality. Workhouse children, he urged, required an 'abundant supply' of food. ${ }^{21}$ Basic tastes should also be gratified, since unpalatable food was simply wasted: 'when it is really disliked it is not eaten, but is thrown into the waste-tub, and its value is completely lost'. ${ }^{22}$ Meat should not be over-roasted, and peas not boiled to pulp. Inmates liked 'to be able to recognise in the food the materials of which it is composed'. ${ }^{23}$

Wholesome and sufficient food, then, was essential to both bodily and national economies. Such beliefs were evident in Robert Owen's schemes earlier in the century. New Lanarck was equipped with large kitchens, bakehouses and dining rooms where workers could eat, while every worker received a vegetable garden. ${ }^{24}$ Owen was attempting to nourish an entire industrial colony. Kay and Howard were, in differing ways, attempting to translate this principle to the whole city, at the precise historical moment when statistics were bringing urban debility into sharp focus. Howard found urban workers of 'squalid appearance', with 'pale and haggard countenance, premature old age, the slender frame and general deficiency of muscular development as compared with the labouring classes in an agricultural district'. ${ }^{25}$ Farr concluded of slum districts in 1839: 'the energy of the whole population is withered to the roots. 
Their arms are weak, their bodies wasted, and their sensations embittered by privation and suffering'. ${ }^{26}$

Vitalizing these urban areas presented very distinct ecological and technological problems. In 1897's How London lives, Gordon observed that the metropolis 'grows hardly any of its own food', and required enormous national and global food supplies. ${ }^{27}$ Home brewing and baking had long been in terminal decline, while many families lacked cookers, sanitary storage facilities and basic utensils, or even knowledge of how to cook. ${ }^{28}$ Urban residents, then, were particularly reliant on shops, cookhouses, pubs and street vendors for their food, which left them exposed to the mendacities of those selling adulterated, unwholesome, substandard or diseased products. I want now to examine three aspects of this problem: adulteration, the milk supply and meat.

\section{Adulteration and public analysis}

Sporadic regulations to curb the duplicitous practices of traders and companies date back centuries, and in the early nineteenth century some renewed efforts were made to control adulteration. ${ }^{29}$ The material constitution of bread, for example, was theoretically regulated by laws of 1822, 1836 and 1837. But adulteration thrived in industrializing Britain. In the spirit of laissez-faire, John Bright famously observed that adulteration was 'a part of trade', almost a sign of a vigorous economy: numerous trade books and pamphlets openly advised how to adulterate provisions. ${ }^{30}$ But for others, it was precisely this sloppiness that allowed debased, diluted or mislabelled food to enter circulation, seriously compromising collective vitality. Several investigations, notably Accum's Treatise on the adulterations of food (1820) and Mitchell's Treatise on the falsification of food (1848), argued forcefully and, occasionally, luridly that adulteration was endemic. The urban poor were, predictably, most vulnerable to such nefarious practices, as the Owenite George Jacob Holyoake protested in 1843:

The worst food comes to the poor, which their poverty makes them buy and their necessity makes them eat. Their stomachs are the waste-baskets of the State. It is their lot to swallow all the adulterations on the market. $^{31}$

Schools, hospitals and workhouses, which frequently bought food supplies in bulk below market price, were particularly exposed to adulteration. Finally, adulteration cost the treasury an estimated seven million pounds annually, as the chemist Arthur Hassall complained: 'adulteration is therefore a great national question, closely affecting the pocket of the consumer, the revenue, and the health and morals of the people'. ${ }^{32}$

Adulteration was acknowledged as a particularly acute problem in cities, and it is no coincidence that the most historically significant exposé of the practice came in London. From 1850, Hassall began routinely sampling and testing London's food. His reports, published in the Lancet, were instrumental in making adulteration known to a wider public: they depicted cheese-mites, flakes of toxins and chalk, and weevils. ${ }^{33}$ Hassall concluded that pure food was almost impossible to find in London. This threat 
to urban vitality was, moreover, the direct consequence of economic liberalism, being 'entirely unnatural ... it has sprung up under a careless and loose state of things, and it is the duty of the State to interpose its authority for the prevention of adulteration'. ${ }^{34} \mathrm{~A}$ Select Committee on Adulteration was appointed in 1855, leading to the first Adulteration Act (1860); this, however, was permissive, and the few public analysts appointed to monitor food quality were legally unable to purchase samples themselves. Only with the 1875 Sale of Food and Drugs Act was a system of food analysis made compulsory. 35

The establishment of this network of analysis was necessarily a rather protracted process. In 1874, the Society of Public Analysts (SPA) was formed, to give analysis institutional and professional coherence. ${ }^{36}$ Its first task was actually to define adulteration, which the 1875 Act had failed to do: the state itself, contra Hassall, was not directly regulating food. The ensuing definition (deliberate addition of injurious or specious materials, abstraction of vital substance, or imitation), accompanied by workable techniques of detection and levels of acceptable impurity, were established and circulated to appropriate officials, including County Clerks of the Peace and Medical Officers of Health (MOHs). But without a firmly established career structure for professional chemists, local authorities found it hard to find qualified men, and sometimes appointed existing MOHs, who often lacked both time and appropriate skills. 'There are not a dozen competent analysts in the kingdom,' grumbled one SPA member. ${ }^{37}$ Additionally, the SPA struggled to establish credibility and objectivity. It presented itself as practical, rather than academic, peopled 'not by wealthy dilletanti or men receiving grants from research funds, but by persons daily and actively engaged in carrying out the complex and tedious duties thrown upon them by an Act of Parliament'. ${ }^{38}$ It also styled itself as a public body, as opposed both to the Inland Revenue chemists at Somerset House, who acted as judges in disputed cases, and to trade interests, represented in periodicals like The Grocer, who routinely interpreted the SPA as meddling in trade affairs. Somerset House chemists, for example, were depicted by the SPA in terms reminiscent of the Circumlocution Office in Dickens's Little Dorrit: 'bound down...by the benumbing shackles of red tape, and the deadweight peculiar to an old-established and somnolent Government Department' 39

Standardizing this system of inspection, analysis, data recording and prosecution proved difficult. Analysts were supposed to receive food and subject it to a set of chemical tests. But the 1875 Act, while making the appointment of analysts mandatory, did not compel either inspection or the physical act of analysis, although MOHs, nuisance inspectors, police constables, inspectors of weights and measures and market inspectors were all legally empowered to procure samples. One analyst argued in 1893 that 'there are hardly two authorities in the country who work the act uniformly and consistently'. ${ }^{40}$ By this date, 27 boroughs and 4 counties had produced no results whatsoever in the 18 years of the Act's operation. Those who zealously pursued their task often ran into practical difficulties. Since most early analysts were multi-purpose chemists who analysed anything a local authority wanted (illumination levels, water), they frequently had to share laboratory space, while purchasing requisite equipment (air-baths, balances, microscopes) could prove extremely difficult, especially in rural 
areas. Inspectors, when appointed, had to avoid becoming known to grocers and dairymen. Their samples required assiduous sealing, labelling and packaging. Analysts grew weary of receiving leaking, decaying or unidentified samples.

Amendments to the Sale of Food and Drugs Act, in 1879 and 1899, clarified legal matters and extended the reach of the legislation to almost everything consumed by humans, with the exception of water. Despite confusions over analytical methods, and regional idiosyncrasies, the SPA routinely aggregated local data and demonstrated that national rates of adulteration were falling. The amount of adulterated samples nationally was 16.2\% between 1877 and 1881; in 1890, the figure was only 11.2\%. Gone were the days when milk was rumoured to teem with sheep's brains. Some SPA members were urging that analytical focus be extended to a wider array of consumer articles, including wallpaper, vermin killers and yeasts. By 1885, the eminent analyst Charles Cameron declared that 'at present very few articles are liable to adulteration save milk and butter'. ${ }^{41}$ This was, however, a major exception. As the eminent lactochemist Paul Vieth complained in the same year: 'we have been devoted this past nine years almost exclusively to analytical work relating to milk'. ${ }^{42}$ It is to this perplexing and protean fluid that we now turn.

\section{An impossible standardization? Milk and dairying}

'Milk', stated the chemist George Wigner, was 'a model food ... a complete food ... It is a model food because it is nature's own food, designed for the sustenance of the young of animals, and, as such, it contains and furnishes all the nutritive properties in due proportion required by a growing animal. ${ }^{43}$ This most ambrosial of nature's delights was also the most easily and regularly adulterated: the 1850s Lancet investigations found some samples with up to 50\% added water. Other forms of adulteration included the extraction of cream or addition of salt or starch to generate density. Milk supplied to workhouses, grumbled Smith, was particularly adulterated: 'there can be no doubt that the deficient supply of milk in some of its forms is one of the most prominent evils in the present system of Poor Law dietaries'. ${ }^{44}$ Children ingesting such milk could suffer from 'diarrhoea, atrophy, and the multitudinous diseases which told so terribly on the infant portion of the population'. 45

The SPA immediately acknowledged the problem with milk:

As there is no more important article of diet than cows' milk, and as no kind of food is more subject to adulteration, it becomes a matter of the greatest importance to Public Analysts as well as to milk consumers, that a safe and proper standard of the quality of cows' milk should be generally accepted. ${ }^{46}$

Their quest was twofold: to define 'normal' milk, and then to prescribe accurate, replicable techniques for its detection. Neither target proved easy. Milk, a complex mixture of water, fats, proteins, sugars and salts, is not a naturally homogeneous substance. Numerous factors determined the fluctuating ratio of these elements, from the cow's species and diet to its general health and, some said, emotional condition or even skull shape. Hassall concluded that the main factors were the age of 
the cow, the time after calving, food, temperature, weather, and the time and frequency of milking'. ${ }^{47}$

The first SPA standards, of 1875, were set deliberately low to avoid penalizing honest farmers whose cows simply produced weak milk. But problems arose, since the official analytical method, developed by the splenetic chemist James Wanklyn, failed to sufficiently dry the precipitate, and consequently underestimated the amount of fat in the sample. ${ }^{48}$ Sceptical analysts began adopting alternative methods, which proliferated, and standardization became consequently impossible: results produced via different apparatuses were simply incommensurable. ${ }^{49}$ As the Public Analyst for Kent, Matthew Adams, observed:

I was soon convinced that although any one man, working in his own special way, with his own special apparatus, might, for himself, obtain concordant results, there is no such concordance to be expected between different workers employing different processes, or may be (sic) slightly different forms of apparatus, or merely the personal equation even, is enough to create discordance. ${ }^{50}$

Professional anarchy was only avoided after the SPA's exhaustive 1883-86 review of available systems, which led to Wanklyn's technique and standard being jettisoned and replaced by Adams's 'paper-coil' technique, and norms being correspondingly adjusted. ${ }^{51}$ Instruments were becoming simpler and sturdier, enabling the culture of calibration to expand beyond the laboratory: Marchand's butyrometer, for example, which measured the quantity of butter in a sample, was 'easily manipulated by any person of ordinary intelligence'. ${ }^{52}$ Although analysis remained patchy, the most egregious acts of adulteration appeared to be declining, and the deceptive arts moved towards more 'subtle' toning, by mixing whole with condensed or skimmed milk and passing it off as naturally weak. ${ }^{53}$

The establishment of a reliable lactic norm was essential to the development of national standards: 'the possibility of detecting whether or not a specimen of milk has undergone impoverishment, depends obviously on the possibility of assigning a normal composition to milk'. ${ }^{4}$ Two major organizational developments facilitated such normalization. First, the development of larger dairies, which, via railways, drew more milk from greater distances. Small farms collected milk from individual cows, and this jumbled mixture was conveyed by trains to the central dairy, where it was immediately poured into huge chilled vats. A particular cow's milk was thus completely absorbed into the aggregate. Manchester was first supplied with railway milk in 1844; London followed in 1846. Second, the development of dairy laboratories allowed analysts to examine a larger pool of commensurable samples: hence figures became more reliable, or at least more statistically significant. This expansion prevented anomalous samples from distorting figures. The only possible or sensible measurements, then, were averages, taken from the intermingled products of multiple herds and countless udders. The first definitive statistics were produced by Vieth for the Aylesbury Dairy Company. Exploiting the ceaseless stream of milk flowing through his laboratory, he took 120540 samples between 1880 and 1891, concluding that 'normal milk contains ash, proteids, and milk-sugar in the proportion of 2:9:13, ${ }^{55}$ The raw product of cows was becoming thoroughly abstract and statistical, and yielding its secrets in the process. ${ }^{56}$ 
A comparable set of public health concerns crystallized around the material conditions of milk production, of dairies and cowsheds, which were often castigated as filthy and ill-governed. Owing to its perishability, milk was one of the few foodstuffs traditionally produced in any great quantity within cities: 'before the advent of the railways London was practically self-sufficing in this respect. Every dairyman was a cowkeeper, and in the middle of the century from 20,000 to 30,000 cows are said to have been kept in London'. ${ }^{57}$ Aside from the development of railways, the defining event here was the 1865-66 cattle plague. Of 9,531 cows inhabiting the area governed by the Metropolitan Board of Works, for example, over half died. ${ }^{58}$ Thereafter, stringent regulations and escalating land prices drove remaining milk production into the East End, where it slowly declined. ${ }^{59}$ There were only 80 recorded cowkeepers in London by $1914 .^{60}$

In such urban dairies, cows seldom, if ever, saw or ate grass, and were often fed on brewers' grains and distillers' wash, a process Hassall dismissed as 'altogether artificial and unnatural ... the cow quickly becomes worn out and diseased in consequence'. ${ }^{61}$ Their confinement was not simply a result of spatial constrictions: the heat generated by squashing cows together stimulated milk production. 'To transform the cow into a milk-producing machine,' argued the chemist Alexander Winter Blyth, 'the animal must be kept indoors, fed highly, and kept at a temperature of from $65^{\circ}$ to $75^{\circ},{ }^{62}$ Cowsheds were clammy and fetid:

The cow passes daily an immense quantity of semiliquid manure and a large quantity of urine; there is also atmospheric contamination from the lungs, and it is to be remembered that in addition to carbon dioxide, the cow passes from the intestine much marsh gas. ${ }^{63}$

Flatulent air, flakes of skin, plus 'food, hair, woollen threads, cobwebs', were easily absorbed into milk, water and animal feed, which could taint milk or make it positively dangerous. ${ }^{64}$ Milk was an ideal disease vector for typhoid, scarlet fever, foot-and-mouth disease and diphtheria, especially when dirty water was added to milk by adulterators, or used to clean equipment. Following a typhoid outbreak at Buddington Orphan School in 1870, it was reported:

It appeared that the dairy utensils were washed with water impregnated with sewage; and no doubt the milk was at times diluted with the same water, for on one occasion one of the children brought to the Matron of the Institution a tadpole which she had fished out of her mug. ${ }^{65}$

It was also apparent by the 1880s that tuberculosis could spread from cow to man through milk, while bacteriologists confirmed that a single pint of milk contained from 33 to 56 million microbes. ${ }^{66}$ Milk was as delectable for germs as it was for kittens:

The peculiarly rich properties of milk as a food renders it admirably adapted for forming a nutritive medium for the development of various disease (the so-called pathogenic) germs, which are constantly to be found, along with other micro-organisms, in the air and elsewhere. ${ }^{67}$

Pasteurization and sterilization developed as the most efficient techniques to combat this bacterial proliferation. Consumers might often be advised simply to boil their own milk. 
Dairy, milkers and cows should be integrated into a disciplined system: 'name every cow, give her a page in your ledger, and keep an account of her yield throughout the year. Provide the milker with a book or a slate, and require him to weigh the milk from every cow as he draws it'. ${ }^{68}$ Lactic cycles were calculated and udders measured. The undifferentiated herd was atomized into individual cows at the precise time that milk itself was being agglomerated and normalized. Dairy reformers assailed slipshod milking:

Milkers still dip their fingers in the pail; they still use the open pans in damp dairies with brick floors; they churn at any temperature; and handle the butter and make it up without any regard to the quantity of buttermilk still remaining in it. ${ }^{69}$

Spatial reform came via orders of 1879 and 1885, which aimed to delineate, clarify and enforce minimum building standards for dairies and cowsheds, although local authorities were allowed considerable leeway in such enforcement. In London, for example, cows should be given 600 cubic feet each, or 800 if ventilation was imperfect: the epoch of the norm, we might say, had a bovine dimension. ${ }^{70}$ Dairy construction manuals emphasized material factors, like double doors, gauze netting for windows, whitewash and hollow brick walls.

Additionally, local government inspection of such spaces was made more routine, compulsory and expansive. From 1879, inspectors could legally procure samples of milk while it was being delivered from churns and floats. According to the Cheshire $\mathrm{MOH}$, Francis Vacher, 'inspection to be effective must not only be of milk shops and dairies, but of the cow byres and farms'. ${ }^{71}$ The Infectious Disease Notification Act (1890) could be used to intercept milk arriving at railway stations: if it was found to harbour disease, milk might be followed back to the farm. Some municipalities began using tuberculin to diagnose diseased animals. ${ }^{72}$ By 1901, for example, all farms supplying milk to Glasgow Corporation Fever Hospitals were testing cows with tuberculin. $^{73}$ The previous year, the same municipality undertook 1220 visits to cowsheds, and 13919 dairy cows were inspected.

By the 1890s dairies and cowsheds were disappearing from towns, and in 1899 the first milk depot was established at St Helens. ${ }^{74}$ Dairying, for all its diversity, was showing slow but sure signs of industrialization. ${ }^{75}$ Bacteriology opened the possibility of scientific cheesemaking, while the concentration of milk in one location made pasteurization more economically feasible. Some dairies were becoming machinated, knitted together by lifts, tramways, hoists and pipes. The first glass bottles were used from the mid-1880s, although they did not become general until the twentieth century: only 50\% of London's milk was bottled and pasteurized in the 1920 s. $^{76}$ Technological contrivances like milking machines, which could be sterilized, removed the likelihood of germs spreading from filthy milkers. The interface between bovine and human worlds was becoming gentler: electroplated tubes, it was held, were 'useful in case of sore teats'. 77

The pinnacle of Victorian lacto-engineering was the station of the Aylesbury Dairy Company, founded in 1865 to supply London with rail-borne milk. The company's 
model farm, founded in 1884 at Itchingfield, near Horsham, drew the following eulogy in 1887:

When he [Alfred Allen] got out of the train he thought he was in Arcadia, and on going through the premises he saw he was in Hygeia, and was bound to confess that the two words were not always synonymous as they were in the present case. ${ }^{78}$

This fusion of the pastoral and the sanitary included a positively palatial 1200 cubic feet of airspace per cow, and genuinely scientific dairying. 'A more extended and thorough control over the milk passing through the business is executed than exists anywhere else in the world,' concluded The Analyst of Vieth's lactic domain. ${ }^{79}$ This was a sanitarian's dream: a cleansed, homogeneous product, aggregated from many herds, was secured and tested. Aylesbury showed that technical control and monitoring were not incompatible with a successful business: the technological mediation of market and public was evolving.

Machinated dairying systems like Aylesbury were explicitly designed to generate public faith in the purity of food. Consumption of milk was rising in Britain, although it was still disproportionately consumed by the middle classes. As the bacteriologist and pathologist responsible for monitoring Manchester's milk supply, Sheridan Delépine, declared in 1909, anonymous, routine expertise was necessarily being interposed between producer and consumer:

The inhabitant of large towns has generally no access to the sources of his food; he is seldom able to satisfy himself by personal observation of the genuineness and soundness of the articles offered to him for consumption, and has to depend upon the knowledge, skill and vigilance of persons appointed for the purpose of protecting him against the dangers associated with insufficient or unsound food supplies. ${ }^{80}$

Such mediated production would become our norm, but it is unique to contemporary, Western societies. It was particularly unique in 1887, when most milk was still produced on small local farms. A similar story can be seen with the production of meat.

\section{Changing topologies of meat: from slaughterhouse to abattoir}

Nineteenth-century Britain, according to Thomas Walley, principal of Edinburgh Royal Veterinary College, was 'the greatest beef-eating country in the world'. ${ }^{81}$ Meat-eating, national vitality, status and masculinity have, of course, been synonymous, in Britain and elsewhere, for centuries. ${ }^{82}$ Nineteenth-century physiological science demonstrated the vitality of carnivores. Liebig, for example, argued that meat was essential to repair damaged tissue: it strengthened bodies, cities and nations. Across the century, global trade and refrigeration techniques drove prices down while expanding supply, in theory democratizing meat consumption. ${ }^{83}$ Gordon estimated that fin-de-siècle London received 380000 tons of meat annually. ${ }^{84}$ This meat was exposed to the same scrutiny as milk, but generated somewhat different issues. Like water, it fell beyond the formal 
remit of the public analyst, being essentially unadulterable: unwholesome or diseased meat was the primary issue, which became the responsibility of Medical Officers of Health, sanitary officials, heads of markets and veterinarians.

The major object of concern was the private slaughterhouse. There were over 1400 of them in London alone in $1874 .{ }^{85}$ Traditionally clustered round old markets and animal trades like knackery and tanning, slaughterhouses were often simply converted sheds or cellars, wooden, filthy and ramshackle. Some butchers killed animals in their back parlours:

The sheds, old warehouses and disused stables converted to the grim purpose, have often been shown to be not only unsuitable for the work, but incapable of being made so by alterations; and being situated in the midst of dense populations, seriously affect the health and comfort of neighbours, whilst, being private premises, that cannot be freely inspected, and are often not inspected at all. ${ }^{86}$

Like byres, chicken runs and pigsties, slaughterhouses formed part of the undifferentiated spatial jumble which appalled rationalizers. ${ }^{87}$ Expressing repulsion at their condition quickly became a cliché of sanitary discourse. In Stirling, Chadwick recorded, 'the slaughter-house is situated near the top of the town, and the blood from it is allowed to flow down the public streets'. ${ }^{8}$ Slaughterhouses cast a morbid shadow, or 'moral taint' which coloured the character of the surrounding area. ${ }^{89}$ Children congregated to watch the bloody struggle between slaughterman and beast. During the Ripper murders, one London minister demanded the immediate closure of all Whitechapel's slaughterhouses. ${ }^{90}$

London's butchers, however, obstinately defended their right to kill where and how they chose, and were granted exemption from the 1844 Metropolitan Buildings Act's clauses on noxious businesses. Lax regulation and inspection of cows, limited recordkeeping and dirty railway trucks clearly helped the spread of cattle plague in 1865 . Sick animals were usually quickly sold to unscrupulous butchers, and the meat often 'polished' to disguise disease, or minced and converted into sausages or pies, and sped surreptitiously into towns at night in soundproofed carts. ${ }^{91}$ Some slaughterhouses specialized in processing diseased meat, and in 1855 rumours circulated that a dead circus elephant had been turned into sausages after being sold to a particularly unfussy knacker. ${ }^{92}$

Eating such meat was seldom fatal: it was simply innutritious or cumulatively damaging, as well as revolting to polite sensibilities. However, the discovery that tuberculosis could spread to humans through beef as well as milk added urgency to the campaign for slaughterhouse reform. The public, again, required the protection of experts:

A purchaser with a few pence in his pocket, and the cravings of hunger gnawing at his stomach, is not likely to exercise great discrimination in the purchaser of the necessaries of life; nor can he afford to pay an expert to teach him what to choose, or what to avoid. He, perforce, buys that which to his uneducated senses is most likely to satisfy the predominant feeling of which he is cognizant - hunger. ${ }^{93}$

The meat industry was gripped by collective slackness and turpitude, a product of excessive liberality, which threatened, slowly, to drain national vitality: 
To remedy the evils of the slaughter-house, and the allied evils of sea-borne and inland cattle-trade, would be not only to discharge a manifest moral duty of the community, but also to consult the interests of the bodily health of the nation, ... endangered by the facilities for the slaughter of diseased animals and the sale of their meat which the private slaughter-houses afford. ${ }^{94}$

How were such covert circuits of pathology to be disabled? Slaughter had to be made public, dragged from the shadows and made visible to trained inspectors able to detect tubercles, lesions or evidence of subterfuge. Because many butchers and slaughtermen operated on private property, entrance was difficult and policing hundreds of tiny spaces impractical: "effectual supervision is rendered almost impossible from the fact that the places are scattered over a large area, and that slaughtering is done at most irregular and untimely periods'. ${ }^{95}$ Early legislation here seems, in retrospect, pitiful: in 1874, three meat inspectors were appointed for the whole of London. These men frequently lacked appropriate training. In 1879, Walley complained that there are many of them who are absolutely ignorant of the rules necessary to guide them in their work, or of the evil effects of unhealthy flesh'. ${ }^{96}$ Likewise, moves to regulate slaughterhouse structures only came in 1875, when the Public Health Act enabled local authorities to provide public slaughterhouses, although comprehensive powers to close insanitary slaughterhouses had to wait until 1890. But reformers hoped this legislation would mark a shift from private to public slaughter, or, as they often stated, from slaughterbouse to abattoir.

This distinction between 'slaughterhouse' and 'abattoir' was something of a tactical and lexical simplification. ${ }^{97}$ In the later nineteenth century, the term 'abattoir' was a coyer way of referring to a large, purpose-built, public institution for slaughter and other animal industries. Like the industrial dairy, the abattoir was a social safety valve:

The abattoir, or slaughter-house, is the first kitchen. From this place the cook receives all she has to prepare and send forth. If she receives healthy substance from thence her blunderings will be comparatively harmless... The abattoir, therefore, as the first kitchen, is, if it be well conducted, the safe guard of the house. $^{98}$

The abattoir was a technology of social vitality, a machine for hygienic extermination, ensuring that only wholesome, tasty meat reached the public. It could form part of the engineered landscape around which abstractions like 'national health' would gather meaning:

Public slaughter-houses are almost as necessary to the community as hospitals, sanatoria, public baths, sewerage schemes, public libraries, cheap locomotion etc.... they are needful for the bodily or mental requirements of the people and are supported by an addition to the rates, or by gifts or endowments of private individuals. ${ }^{99}$

The abattoir also eradicated the 'moral taint' of the slaughterhouse by entirely cocooning death. The abattoir was public in a very specific sense: it was permanently open to inspection by public authorities; while the public itself could simply forget about it (today's abattoirs seldom declare their function, being usually indistinguishable from warehouses). 
Early abattoirs were of two kinds: several small slaughterhouses assembled in one space (as at Britain's first abattoir, built in Edinburgh in 1851), or large institutions located at ports for the purpose of immediately slaughtering all incoming live animals (as at Deptford in 1872). But more specialized urban buildings were soon constructed: by 1892, there were 48 municipal abattoirs in Britain. By collecting all animal industries on one site, economies of scale were achieved. Tiny parts of animals (skin, blood, offal, glands) could be accumulated in sufficient quantities to be profitable. Knuckles were processed into hair-oil; hoofs became hairpins. ${ }^{100}$ "The hot blood is much used at the Paris abattoir as baths for weaklings and sufferers from rachitis \&c; while the invalids take it internally, and, it is said, with great benefit,' reported The Builder rather drily in 1881. ${ }^{101}$ Unrecyclable waste (dung, and putrid or tubercular meat) was destroyed or flushed away in the sewers. 'A modern abattoir is a sort of miniature industrial colony,' one student of German abattoirs concluded: some included swimming baths and homes for stray dogs. ${ }^{102}$ Buildings were designed to be sturdy and impervious, threaded with pipes and ventilators which maintained a permanent supply of cleansing, purifying water and air. Trained municipal officials were available to inspect proceedings, ideally in laboratories. In Glasgow, for example, meat inspection was placed under the Corporation veterinary officer, A.M. Trotter, in 1900; it extended to railway stations, wharves and sausage factories. Inspectability was built into abattoirs: the superintendent's office at Chatham abattoir (1904) was positioned 'between the waiting pens and slaughter hall, with windows overlooking each... enabling the inspector to command a full view of the whole of the work done in the slaughter hall'. ${ }^{103}$ Meat 'should be handled as little as possible,' being moved largely by hooks and rails from the point of slaughter through successive stages of dressing, inspection, chilling, storage and transportation. ${ }^{104}$

William Cronon has referred to this whole process as a 'disassembly line'. ${ }^{105}$ The living animal entered at one end, while chilled meat emerged at the other, ready to be transported to urban markets. The abattoir, plugged into transportation networks, allowed slaughter to proceed at new scales and speeds. ${ }^{106}$ Anonymous from the outside, the abattoir was functionally divided within, with pens, slaughter-rooms, dressing spaces and chill-rooms providing an orderly flow. Noelie Vialles, in the only detailed anthropological study of the abattoir, divides this flow into two fundamental elements. The first, 'deanimation', sees the animal immobilized, stunned, killed, suspended and bled: vitality is removed, but still leaves an animal, albeit one devoid of life. The second, 'deanimalization', eradicates the signs of animality, by removing skin and head, then cutting and dressing, producing a purely cultural artefact, or something organic but not biological. ${ }^{107}$ This created, in theory, a completely standard object, divested of animal identity. Meat was thus normalized rather like milk, on the understanding that all human bodies needed the same basic diet, as Cash argued: 'the physiological laws which govern the functions of our various organs appear to be very much the same whether we live in the Orkneys or at Hampstead'. ${ }^{108}$

Something more than 'public health' or 'vitality' is evident in this killing and remaking, of course. There is something fantastic and disconcerting about the idea of death made painless and invisible. Shooting apparatuses, especially those driving a bolt 
into the animal's head, allegedly completely stunned the creature and thus made killing humane and silent: 'in those forms of apparatus in particular which are provided with several silencing chambers the report is so wonderfully deadened that the sound resembles a person clapping his hands'. ${ }^{109}$ Gas and electricity were both deliberately used to kill animals many years before being used on humans. ${ }^{110}$ One early twentiethcentury humanitarian referred to slaughter not as killing but 'euthanasia', as if we were preparing to leave our barbaric past behind and enter world where human vitality and kindness to animals were not mutually exclusive. ${ }^{111}$ As Vialles concludes, such schemes represent an impossible dream of destroying the abattoir's very raison d'etre: 'from this point on, slaughtering was required to be industrial, that is to say large scale and anonymous; it must be non-violent (ideally: painless); and it must be invisible (ideally: non-existent). It must be as if it were not'. ${ }^{112}$

These technological fantasies, which history has since given a disturbing edge, should not, however, blind us to the limits of the industrialization of the meat industry in the early twentieth century. Benjamin Ward Richardson's Model Abattoir Society, for example, had raised little money and found no site for its abattoir in 1893. The law remained muddled, impeding practical and material standardization. Manchester still had 100 private slaughterhouses in 1897, despite the construction of a public abattoir. Birmingham's abattoir was built right in the centre of the city, with no connection to railways, so animals were still driven through streets and their carcasses carted away by trolley. In Leamington Spa, slaughter continued in disused railway arches. As late as 1913 there was still no statutory regulation of slaughtering methods. ${ }^{113}$

\section{Conclusions: the political geography of urban nutrition}

I have outlined several major, if protracted, changes in the regulation of the urban food supply in nineteenth-century Britain. By 1900, food was inspected and analysed, and becoming standardized and packaged: technological and human mediators interposed between producer and consumer to a historically unprecedented extent. In conclusion, I will make some observations about the politics of this regulatory apparatus, and emergent patterns of nutritional geography which were being regulated.

In National styles of regulation, David Vogel argued that British environmental policy since the Victorian period can be characterized, generally, by a high degree of cooperation and trust between industry and government'. ${ }^{114}$ Regulation has been, typically, founded on pragmatism, flexibility and negotiation, and the state's unwillingness to dictate terms to industry. I think Vogel's conclusions can be extended to the regulation of food. The Sale of Food and Drugs Act of 1875, as noted, delegated decisions over the definition and legal levels of adulteration to a body of professional experts who attempted to act in the interests of neither the state nor industry. Analysts were themselves locally appointed, and substantial local autonomy was built into the operation of the system. Much legislation remained permissive: tuberculin testing remained voluntary, for example, until $1964 .{ }^{115}$ 
Local inspectors were encouraged to cooperate and compromise with butchers and dairymen. Vacher urged food inspectors to behave politely: 'courtesy is what everyone has a right to expect from a public official, and its absence is a very grave defect'. ${ }^{116}$ In Glasgow, Trotter observed that meat inspection was proceeding without the need for force or fines. 'The majority of the meat salesmen', he stated 'have cordially assisted the inspectors by acquainting them of country consignments arriving between their visits'. ${ }^{117}$ Inspectors and analysts, in such cases, were able to convince industry that regulation was not antithetical to business, but necessary for both national vitality and private profitability.

I will now make some observations about the new landscape of provision and regulation which was beginning to take shape by 1900. There are, I think, four main aspects to this. First, the question of distance: networks supplying the city with food stretched quite durably over large tracts of space. Meat in particular was shipped in huge quantities from Argentina, the United States and Australasia, while milk was drawn from a pastoral hinterland of farms beyond urban peripheries. Creating the vital city, in other words, involved mammoth reconfiguration of animal geographies. ${ }^{118}$ Second, technological developments: the use of steamships, refrigeration and railways allowed a greater volume of food to circulate more rapidly than at any time in history, while abattoirs and industrial dairies accelerated the speed at which food was processed. Third, there was an increasing sense of spatial differentiation: technologically specific sites were slowly being allocated to the production of milk and meat, in contradistinction to what now appeared, in retrospect, to be an earlier period where urban space and function were not so clearly aligned. Fourth, these networks were physically designed to facilitate routine inspection and analysis. Abattoirs in particular allowed inspectors visual and tactile access to a sizable sample of nutriment entering the urban food supply. The laboratory added another node to this network of inspection. Ideally, as at Aylesbury, the laboratory might be situated within the plant itself, and inspection undertaken coterminously with production.

This new nutritional geography, characterized by distance, technology, differentiation and regulation, emerged gradually and unevenly, and overlaid, without entirely eradicating, an older set of smaller, dispersed, isolated and unregulated spaces. Municipal abattoirs often stood in the midst of an archipelago of scabby old slaughterhouses. Industrialization was also certainly patchy and piecemeal: in 1900, Aylesbury was very much an exception in the world of dairying, and some aspects of the food supply, like baking, were barely mechanized at all before the end of the nineteenth century. ${ }^{119}$ This new geography, most importantly, very much centred on the city. Public analysis was most active and prevalent in the city, while new milk and meat technologies were invariably designed to secure a wholesome urban environment, or a vital city.

The vital city was almost entirely emptied of food production, drawing its animal nutriment through networks which, by channelling, accelerating and mediating a vast flow of vital matter, were beginning to secure food of the quality and quantity which men like Howard had demanded. At this precise historical juncture, the life expectancy of urban residents, especially children nourished with cleansed and screened milk, was 
rising. ${ }^{120}$ Yet this historical process would itself create the conditions for new forms of public health crisis. I will mention two here. First, nutritional networks might grow so large, complex, corporate and mechanized as to become dangerously opaque to public inspection and hence potentially deregulated. Any pathogens entering or flourishing in the system might thus be efficiently distributed to supermarkets and restaurants. Instead of adulterated milk or tubercular meat, our concerns today include e-coli and BSE. ${ }^{121}$ Second, cities might become oversupplied and overfed. Obesity was, to put it mildly, not a problem in Howard's Manchester. In 2005, studies revealed that Manchester was Britain's fattest city (a dubious honour which has since passed to Bradford). ${ }^{122}$ This potential urban hypervitalization was unthinkable in the nineteenth century. Whether these new problems can be solved without fundamentally changing Britain's existing regulatory style remains to be seen.

\section{Acknowledgements}

I would like to thank Kristina Sessa, and the anonymous referees, for their helpful comments on, and suggestions about, this paper.

\section{Notes}

${ }^{1}$ E. Burke, 'Thoughts and details on scarcity', in I. Kramnick, ed., The portable Edmund Burke (London, Penguin, 1999), p. 195.

${ }^{2}$ G. Dodd, The food of London; a sketch of the chief varieties, sources of supply, probable quantities, modes of arrival, processes of manufacture, suspected adulteration, and machinery of distribution, of the food for a community of two millions and a half (London, Longman, Brown, Green \& Longmans, 1856), p. 2.

${ }^{3}$ H. Spencer, 'From freedom to bondage', in T. Mackay, ed., A plea for liberty (1891); in M. Taylor, ed., Herbert Spencer and the limits of the state: the late nineteenth-century debate between individualism and collectivism (Bristol, Thoemmes, 1996), p. 16.

4 For the history of hunger, and more especially the 'socialization' of the problem of hunger, see J. Vernon, 'The ethics of hunger and the assembly of society: the techno-politics of the school meal in modern Britain', American historical review pp. 110 (2005), 693-725. For the Irish famine, see C. Kinealy, The great Irish famine: impact, ideology and rebellion (New York, Palgrave, 2001), and R.J. Scally, The end of hidden Ireland: rebellion, famine and emigration (Oxford, Oxford University Press, 1995).

5 C. Hamlin, Public health and social justice in the age of Chadwick: Britain, 1800-1854 (Cambridge, Cambridge University Press, 1998), pp. 144-45.

${ }^{6}$ R. Howard, An inquiry into the morbid effects of the deficiency of food, chiefly with reference to their occurrence among the destitute poor (London, Simpkin, Marshall, 1839), p. 38.

7 Ibid. p. 2.

${ }^{8}$ Cited in J. Burnett, Plenty and want: a social bistory of diet in England from 1815 to the present day, rev. edn (London, Scolar Press, 1979), p. 178.

9 Howard, Morbid effects, p. 5. 
${ }^{10} \mathrm{~J}$. Phillips Kay, The moral and physical condition of the working classes employed in the cotton manufacture in Manchester, 2nd edn (London, Frank Cass, 1970), p. 24.

11 Ibid. p. 89.

${ }^{12}$ Hamlin, Public bealth, p. 95.

13 Howard, Morbid effects, p. iv.

${ }^{14}$ K. Polanyi, The great transformation: the political and economic origins of our time (Boston, Beacon Press, 1957).

15 The term 'carbohydrate' dates from 1844, and 'protein' from 1838. The terms 'albuminous' and 'nitrogenous' were used interchangeably with 'protein' across the period.

16 Playfair published many of these studies over the years. See e.g. 'On the relation of the food of man to his useful work (I)', Chemical news 9 (12 May 1865), pp. 221-24. Such experiments usually involved simple measurements of the amount of food ingested, and the amount of waste leaving the body in the form of excrement, urine, sweat and exhaled air.

${ }^{17}$ For an assessment of Smith's work, see C.B. Chapman, 'Edward Smith, physiologist, human ecologist, reformer', Journal of medical history 22 (1967), pp. 1-26, and T. Barker, D. Oddy and J. Ludkin, The dietary surveys of Edward Smith: a new assessment (London, Staples Press, 1970).

18 Playfair, 'Food of man', pp. 221-24.

19 F.W. Pavy, A treatise on food and dietetics, physiologically and therapeutically considered, 2nd edn (London, Churchill, 1875), p. 32.

20 E. Smith, Dietaries for the inmates of workhouses. report to the president of the poor law board (London, George Eyre \& William Spottiswoode, 1866), p. 24.

${ }^{21}$ Ibid. p. 51.

22 Ibid. p. 20.

23 Ibid. p. 31.

${ }^{24}$ R. Owen, A new view of society: or, essays on the principle of the formation of human character preparatory to the development of a plan for gradually ameliorating the condition of mankind, 3rd edn (London, Longman, Hurst, Rees, Orme \& Brown, 1817).

25 Howard, Morbid effects, p. 8.

${ }^{26}$ Cited in J. Eyler, Victorian social medicine: the ideas and methods of William Farr (Baltimore, Johns Hopkins University Press, 1979), p. 124.

27 W.J. Gordon, How London lives: the feeding, cleansing, lighting and police of London; with chapters on the post office and other institutions, new edn (London, Religious Tract Society, 1897), p. 14.

28 Burnett, Plenty and want, pp. 15-20, 185-87.

29 See e.g. J.D. Blaisdell, 'To the pillory for putrid poultry: meat hygiene and the medieval London butchers, poulterers and fishmongers' companies', Veterinary bistory 9 (1997), pp. $114-24$.

30 Cited in G. Venables-Vernon, 'Dairy farming', Nineteenth century 128 (Feb. 1896), p. 282.

31 Cited in Burnett, Plenty and want, p. 145.

32 A. Hill Hassall, Food: its adulteration, and the methods for its detection (London, Longmans, Green, 1876), p. 849.

33 See e.g. A.H. Hassall, Report to the Right Hon. William Cowper, M.P., President of the General Board of Health, on the microscopical examination of the metropolitan water supply (London, General Board of Health, 1857), and Food and its adulterations; comprising the reports of the Analytical Sanitary Commission of the Lancet for the years 1851 to 1854 Inclusive (London, Longman, Brown, Green \& Longmans, 1855). See also C. Hamlin, A 
science of impurity: water analysis in nineteenth-century Britain (Berkeley, University of California Press, 1990).

34 Hassall, Food, p. 870 (emphasis added).

35 For a comprehensive analysis of this and other legislation on adulteration, see M. French and J. Phillips, Cheated not poisoned: food regulation in the United Kingdom, 1875-1938 (Manchester, Manchester University Press, 2000). See also Burnett, Plenty and want, pp. 257-62.

36 B. Dyer, The Society of Public Analysts and other analytical chemists: some reminiscences of the first fifty years (Cambridge, Heffer, 1932).

37 Augustus Voelker, cited in R.C. Chirnside and J.H. Hammence, The 'practicing chemists': a bistory of the Society for Analytical Chemistry 1874-1974 (London, Society of Analytical Chemists, 1975), p. 9.

38 J. Muter, 'Society of Public Analysts', Analyst 5 (Feb. 1880), pp. 15-16.

39 Analyst 8 (Apr. 1893), p. 114.

40 O. Hehner, 'President's annual address', Analyst 8 (Feb. 1893), p. 36.

41 C. Cameron, 'Notes on the operation in Dublin of the acts relating to adulteration', Analyst 10 (Oct. 1885), p. 179.

42 P. Vieth, 'Discussion of Mr. Adams' new milk process', Analyst 10 (May 1885), p. 85.

43 G.W. Wigner, 'Abstract of a lecture on pure milk', Analyst 9 (Oct. 1884), p. 174.

${ }^{44}$ Smith, Dietaries, p. 48.

45 J. Chalmers Morton, 'On London milk', Journal of the Royal Society of Arts 14 (15 Dec. 1865), p. 77.

46 A. Hill, 'Milk standards', Analyst 1 (31 May 1876), p. 40.

47 Hassall, Food, p. 350.

48 This method entailed first heating milk in a water-bath until the solids alone remained. These solids were split into 'fat' and 'solids-not-fat' (sugars and minerals) via the application of ether, and then the 'solids-not-fat' were separated with alcohol. The technique was fully described by J. Wanklyn, Milk-analysis: A practical treatise on the examination of milk and its derivatives, cream, butter and cheese (London, Truber, 1886). Wanklyn's standard was $2.5 \%$ fat to $9 \%$ solids-not-fat.

49 A point made in greater detail by I. Hacking, 'The self-vindication of the laboratory sciences', in A. Pickering, ed., Science as practice and culture (Chicago, Chicago University Press, 1992), pp. 29-62.

50 M. Adams, 'On a new method for the analysis of milk', Analyst 10 (Mar. 1885), p. 46.

${ }^{51} \mathrm{Ibid}$. The new standard was 3\% fat to $8.5 \%$ solids-not-fat, and was now identical to that of the government chemists at Somerset House.

$52 \mathrm{~J}$. Long, British dairy-farming, to which is added a description of the chief continental systems (London, Chapman \& Hall, 1885), p. 60.

53 P.J. Atkins, 'Sophisticated detected: or, the adulteration of the milk supply, 1850-1914', Social bistory 16 (1991), p. 331.

54 Wanklyn, Milk-analysis, p. 37 (emphasis added).

55 P. Vieth, 'Fat-extraction and fat-calculation in milk analysis', Analyst 16 (Nov. 1891), p. 206.

56 A similar process for grain is depicted by W. Cronon, Nature's metropolis: Chicago and the Great West (New York, Norton, 1991), pp. 97-147.

57 H. Smith, 'The food of London (II)', Quarterly review 191 (1900), p. 118.

58 Burnett, Plenty and want, pp. 200-201.

59 P.J. Atkins, 'London's intra-urban milk supply, c.1790-1914', Transactions of the Institute of British Geographers, n.s. 2 (1978), p. 383. 
60 J. Burnett, Liquid pleasures: a social history of drinks in modern Britain (London, Routledge, 1999), p. 33.

61 Hassall, Food, p. 404.

62 A. Winter Blyth, A manual of public health (London, Macmillan, 1890), p. 274.

63 Ibid. pp. $274-75$.

${ }^{64}$ C.M. Aikman, Milk: its nature and composition: a hand-book in the chemistry and bacteriology of milk, butter and cheese (London, Adam \& Charles Black, 1895), p. 109.

65 A. Smee, Milk in health and disease (London, Edward Newman, 1875), p. 10.

66 On tuberculosis and milk see B. Orland, 'Cow's milk and human disease: bovine tuberculosis and the difficulties involved in combating animal diseases', Food and history 1 (2003), pp. 179-202; P. Atkins, 'Milk consumption and tuberculosis in Britain, 1850-1950', in A. Fenton, ed., Order and disorder: the health implications of eating and drinking in the nineteenth and twentieth centuries (East Linton, Tuckwell Press, 2000).

${ }^{67}$ Aikman, Milk, p. 68.

${ }^{68}$ Long, British dairy-farming, p. 300.

69 Ibid. p. 6.

70 Blyth, Manual of public health, p. 278. On normalization, see G. Canghuilhem, The normal and the pathological, trans. C. Fawcett (New York, Zone Books, 1991).

71 F. Vacher, The food inspector's handbook, 4th edn (London, Sanitary Publishing Company, 1905), p. 170.

72 K. Waddington, "To stamp out "so terrible a malady": bovine tuberculosis and tuberculin testing in Britain, 1890-1939', Medical history 48 (2004), pp. 29-48. See also D. Dwork, 'The milk option: an aspect of the history of the infant welfare movement in England, 1898-1908', Medical history 31 (1987), pp. 51-69.

73 A.M. Trotter, 'The inspection of meat and milk in Glasgow', Journal of comparative anatomy and therapeutics 14 (1901), p. 88.

74 A. Wohl, Endangered lives: public health in Victorian Britain (London, J.M. Dent, 1983), pp. 32-33. See also Burnett, Liquid pleasures, p. 38.

75 For an analysis of this in an American context, see E.M. DuPuis, Nature's perfect food: how milk became America's drink (New York, NYU Press, 2002).

76 Burnett, Liquid pleasures, p. 42.

77 Long, British dairy-farming, p. 242.

78 'The visit of the Society of Public Analysts to the farms of the Aylesbury Dairy Company on the $9^{\text {th }}$ June, 1887', Analyst 12 (July 1887), p. 188. Alfred Allen was public analyst for Sheffield; 'Hygeia' was the name given to B.W. Richardson's model city of health (1876).

79 Ibid. p. 188.

80 S. Delépine, 'The Manchester milk supply from a public health point of view', Manchester Statistical Society, Transactions 56 (1909-10), pp. 1-2.

81 T. Walley, A practical guide to meat inspection (Edinburgh, Young J. Pentland, 1890), p. 3.

82 See e.g. T. Morton, Shelley and the revolution in taste: the body and the natural world (Cambridge, Cambridge University Press, 1994); N. Fiddes, Meat: a natural symbol (London, Routledge, 1991); K. Thomas, Man and the natural world: changing attitudes in England 1500-1800 (Oxford, Oxford University Press, 1996); C.J. Adams, The sexual politics of meat: a feminist-vegetarian critical theory, 2nd edn (New York, Continuum, 2000).

83 For economic questions, see R. Perren, The meat trade in Britain 1840-1914 (London, Routledge, 1978). See also V. Knapp, 'The democratization of meat and protein in late-eighteenth and nineteenth century Europe', Historian: journal of history 60 (1997), pp. 541-51. 
84 Gordon, How London lives, p. 23.

85 R.S. Ayling, Public abattoirs: their planning, design and equipment (London, E. \& F. Spon, 1908), p. 4.

86 M.E. Haweis, 'Cattle ships and abattoirs', Westminster Review 143 (1895), p. 679.

87 For a compelling account of slaughterhouse reform and urban space, see P. Joyce, The rule of freedom: liberalism and the modern city (London, Verso, 2003).

88 Forrest, cited in E. Chadwick, Report on the sanitary condition of the labouring population of Great Britain, ed. M.W. Flinn (Edinburgh, Edinburgh University Press, 1965), p. 108.

89 Manchester City Council, Minutes of Proceedings, 15 Jan. 1869, p. 291.

$90 \mathrm{~J}$. Turner, Reckoning with the beast: animals, pain and humanity in the Victorian mind (Baltimore, Johns Hopkins University Press, 1980), p. 134.

91 'Polishing' was the smearing of the meat of diseased animals with the fat from a healthy carcase to produce a bogus sheen or gloss. See Perren, Meat trade, p. 67.

$92 \mathrm{H}$. Ritvo, The animal estate: the English and other creatures in the Victorian age (Cambridge, MA, Harvard University Press, 1987), p. 237.

93 Walley, Practical guide, p. 3.

${ }^{94}$ Revd John Verschoyle, Slaughter-house reform, cited in Ayling, Public abattoirs, p. 11.

95 Cited in C. Cash, Our slaughter-house system: a plea for reform (London, George Bell \& Sons, 1907), pp. 23-24.

96 T. Walley, The four bovine scourges: pleuropneumonia, foot-and-mouth disease, cattle plague, tubercle (scrofula). With an appendix on the inspection of live animals and meat (Edinburgh, MacLachlan \& Stewart, 1879), p. 202; cited in Walley, Practical guide, p. 169.

97 For the genesis of the term 'abattoir' see N. Vialles, Animal to edible (Cambridge, Cambridge University Press, 1994), pp. 22-27.

98 B. Ward Richardson, 'Public slaughter-houses: a suggestion for farmers', New Review 8 (Jan.-June 1893), p. 631.

99 Ayling, Public abattoirs, p. 25.

100 For an exhaustive list of the uses to which inedible animal parts were put, see Cash, Our slaughter-house system, pp. 66-67.

101 'Abattoirs for St. Petersburg', Builder 41 (17 Sep. 1881), p. 352.

102 H. Heiss, 'The German abattoir', in Cash, Our slaughter-house system, p. 144.

103 Ayling, Public abattoirs, p. 42.

104 Cash, Our slaughter-house system, p. 52.

105 Cronon, Nature's metropolis, pp. 211, 229.

106 For a comprehensive discussion of the abattoir-railway-meat-packing company nexus in a Canadian context, see I. MacLachlan, Kill and chill: restructuring Canada's beef commodity chain (Toronto, University of Toronto Press, 2002).

107 Vialles, Animal to edible, p. 73.

108 Cash, Our slaughter-house system, p. 73.

109 Heiss, 'German abattoir', p. 164.

110 Benjamin Ward Richardson performed experiments involving numerous substances, including coal gas, carbon monoxide and electric currents. See e.g. his Hygeia: a city of health (London, MacMillan \& Co, 1876) and 'The painless extinction of life', Popular Science Monthly 26 (1884-85) pp. 641-52. See also 'Slaughtering by electricity', Electrician 10 (1883), pp. 247, 276.

111 J. Verschoyle, Slaughter-house reform (London, Humanitarian League, 1900-1910), p. 15.

112 Vialles, Animal to edible, p. 22.

113 J. Galsworthy, The slaughter of animals for food (London, Daily Mail, 1913), p. 6. 
${ }^{114}$ D. Vogel, National styles of regulation: environmental policy in Great Britain and the United States (Ithaca, NY, Cornell University Press, 1986) p. 26. Vogel finds these trends apparent in regulation like the Alkali Acts of 1863 and 1874.

115 Waddington, 'To stamp out "so terrible a malady", p. 43.

116 Vacher, Food inspector's handbook, p. 4.

117 Trotter, 'Inspection', p. 86.

118 On animal geographies, see C. Philo and C. Wilbert, eds, Animal spaces, beastly places: new geographies of human-animal relations (London, Routledge, 2000); J. Wolch and J. Emel, eds, Animal geographies: place, politics and identity in the nature-culture borderlands (London, Verso, 1998); S. Whatmore, Hybrid geographies: natures, cultures, spaces (London, SAGE, 2002).

119 Burnett, Plenty and want, pp. 140-41.

120 W.F. Bynum, Science and the practice of medicine in the nineteenth century (Cambridge, Cambridge University Press, 1994), pp. 223-24.

${ }^{121}$ On BSE, see P. Van Zwanenberg, BSE: risk, science and governance (Oxford, Oxford University Press, 2005). The only historical study of e-coli, to my knowledge, is R. Piechocki, Das berïhmteste bakterium: 100 jahre escherichia-coli-forschung (Cologne, Aulis Verlag Deubner, 1989), although Eric Schlosser discusses the rapid spread of the disease through industrialized food networks in Fast food nation (New York, Harper Perennial, 2002), pp. 194-204.

122 'Bradford named UK's fattest city', Guardian (1 Feb. 2006). Manchester has fallen to third in the rankings in 2006. For some of the historical origins of the 'epidemic' of obesity and the concerns surrounding it, see P. Stearns, Fat history: bodies and beauty in the modern West (New York, New York University Press, 1997). 